\title{
Evaluation of Non-Feed Removal Induced Molting in Laying Hens
}

\author{
Hnin Yi Soe ${ }^{1}$, Yukihiro Makino ${ }^{2}$, Norio Uozumi², Masato Yayota ${ }^{3}$ and Shigeru Ohtani ${ }^{3}$ \\ ${ }^{1}$ United Graduate School of Agricultural Science, Gifu University, Gifu 501-1193, Japan \\ ${ }^{2}$ Poultry Nutrition Research and Development, Kyodo Shiryo Co., Ltd., Kamisu 314-0103, Japan \\ ${ }^{3}$ Faculty of Applied Biological Sciences, Gifu University, Gifu 501-1193, Japan
}

\begin{abstract}
This study aimed to evaluate the effects of a molt diet on molt induction and the post-molt performance of laying hens. White Leghorn hens (age, $62 \mathrm{wk}$ ) were randomly divided into three groups (two experimental, one control). After a 4-wk preliminary period, one group (control) was continuously fed a corn-soybean-based layer ration ad libitum. Molting was induced in the other groups by starvation (MS) or with feed (MF). In the MS group, the feed was withdrawn for $2 \mathrm{wk}$; this was followed by feeding of a layer ration on alternate days for $1 \mathrm{wk}$ and then ad libitum. The MF group was fed ad libitum a low-protein and low-energy diet based on corn, wheat bran, and corn gluten feed for $4 \mathrm{wk}$; this was followed by ad libitum feeding of a layer ration. Egg production, egg quality, and feed intakes were measured throughout the experimental period; ovary and oviduct weights and heterophil: lymphocyte $(\mathrm{H}: \mathrm{L})$ ratios were measured during molting. During molting, the feed intake in the MF group was lower than that of the control; body weights of the molted groups were significantly reduced. Additionally, the MS group totally ceased egg production within $8 \mathrm{~d}$; in the MF group, egg production decreased to $3.8 \%$ by $\mathrm{d} 10$. On d 10 of molting, the H:L ratio of the MF group was lower than that of the MS group. On d 14, the ovaries and oviducts of the molted groups were distinctly lighter than those of the control. Throughout the post-molt period, egg production and egg shell thickness of the molted groups improved; but there were no significant differences. Additionally, the eggs of the MF group were heavier than those of the MS and control groups. This study suggests that feeding of a low-protein and low-energy diet effectively induces molting and increases post-molt production.
\end{abstract}

Key words: induced molting, molt diet, post-molt performance, stress

J. Poult. Sci., 44: 153-160, 2007

\section{Introduction}

Since 1960's, forced molting has become the dominant replacement program for the U.S. egg industry (Ahmad and Roland, 2003). In 1987, it was estimated that approximately $60 \%$ of the hens in USA and $90 \%$ of the hens in California were force-molted (Holt, 1992). Molt induction after 1 year of egg production is commonly practiced by the commercial egg industry to expand the productivity of hens for a second laying cycle and to enhance albumen and shell quality, which normally deteriorate by the end of the first laying cycle (Keshavarz and Quimby, 2002). The most commonly practiced method of molt induction is feed withdrawal for several days to hasten the process of entering into a second egglaying cycle (North and Bell, 1990). This is an efficient method to induce molting because it is management friendly, economically advantageous, and results in satisfactory post-molt performance for the commercial layer industry (Brake, 1993). However, increased public awareness of the animal stress associated with feed withdrawal has led researchers to investigate alternative molting processes (Holt,

Received: September 27, 2006, Accepted: November 8, 2006

Correspondence: Dr. S. Ohtani, Faculty of Applied Biological Sciences, Gifu University, 1-1 Yanagido, Gifu 501-1193, Japan.

(E-mail: sohtani@gifu-u.ac.jp) 
2003; Ricke, 2003). Alternative methods without total feed withdrawal are highly desirable (Ruszler, 1998; Park et al., 2004). Methods using partial feed restriction are called non-feed-removal techniques, and these are more preferred as they are not less effective from the viewpoint of the post-molt egg production performance (Biggs et al., 2003).

The objective of the study was to investigate the effects of molting with feed, which appeared to be less stressful than conventional feed withdrawal, on molt induction, post-molt production, and post-molt egg quality in layers.

\section{Materials and Methods}

The experiment was conducted using 300 Single Comb White Leghorn hens of the Julia strain (age, 62 to $78 \mathrm{wks}$ ). The hens were kept in individual cages situated in a windowless two-tier cage house and received $15 \mathrm{~h}$ of light and $9 \mathrm{~h}$ of darkness per day. The experiment was initiated in August 2004 and was completed in December 2004. The hens were allowed $4 \mathrm{wk}$ for acclimation (preliminary period). During this time, they were fed a conventional layer ration (Table 1) ad libitum and allowed full access to water. Except for the molt-inducing period, this diet was fed until the end of the experiment. The experimental period consisted of a 4-wk molt-inducing period followed by an 8-wk post-molt production period. After the acclimation was completed, the hens were divided into three groups (two experimental, one control) each consisting of 4 replicates with 20 hens each and with minimal variation in the rate of egg production. During the moltinducing period, one group (control) was consistently fed a layer ration based on corn and soybean meal ad libitum. Molting was induced in the other groups by starvation (MS) or with feed (MF). In the MS group, the feed was withdrawn for $2 \mathrm{wk}$; this was followed by feeding of a layer ration on alternate days for $1 \mathrm{wk}$ and then ad libitum. The MF group was fed a low-protein and low-energy molt diet (Table 1) based on corn, wheat bran, and corn gluten feed ad libitum for $4 \mathrm{wk}$. The light period was reduced to $12 \mathrm{~h} / \mathrm{d}$. During the post-molt production period, hens were returned to the conventional layer ration and gradually received $15 \mathrm{~h}$ of light/d.

During the acclimation and experimental periods, egg production, shell breakages, egg weight, and
Table 1. Ingredient and composition of diets

\begin{tabular}{lcc}
\hline \hline Ingredient and content & Layer ration & Molt diet \\
\cline { 2 - 2 } Corn & \multicolumn{1}{c}{$\%)$} & \\
\cline { 2 - 3 } Defatted rice bran & 60.600 & 34.500 \\
Wheat bran & 2.000 & 10.000 \\
Corn gluten feed & - & 30.000 \\
Soybean meal & - & 20.000 \\
Rapeseed meal & 14.300 & - \\
Gluten meal & 3.000 & - \\
Fish meal & 4.000 & - \\
Animal fat & 3.000 & - \\
Calcium carbonate & 2.500 & - \\
Dicalcium phosphate & 9.205 & 4.700 \\
Salt & 0.800 & 0.660 \\
DL-methionine & 0.300 & - \\
Choline chloride & 0.055 & - \\
Paprika & 0.040 & 0.040 \\
Vitamin-mineral premix & & - \\
Calculated content $(\%)$ & 0.100 & 0.100 \\
CP & 0.100 & 13.7 \\
ME (Mcal/kg) & 17.3 & 2.27 \\
Ca & 2.85 & 2.11 \\
Av.P & 4.02 & 0.40 \\
Na & 0.36 & 0.04 \\
\hline Provi & 0.15 & \\
\hline & &
\end{tabular}

${ }^{1}$ Provided per kilogram of diet: vitamin A, $8000 \mathrm{IU}$; vitamin $\mathrm{D}_{3}$, $1600 \mathrm{IU}$; vitamin $\mathrm{E}, 5 \mathrm{IU}$; vitamin $\mathrm{K}_{3}, 1 \mathrm{mg}$; vitamin $\mathrm{B}_{1}, 0.7 \mathrm{mg}$; vitamin $\mathrm{B}_{2}, 2.5 \mathrm{mg}$; vitamin $\mathrm{B}_{6}, 2.5 \mathrm{mg}$; niacin, $10 \mathrm{mg}$; pantothenic acid, $2 \mathrm{mg}$; folic acid, $0.25 \mathrm{mg}$; vitamin $\mathrm{B}_{12}, 0.003 \mathrm{mg}$; biotin, $0.1 \mathrm{mg}$; manganese, $50 \mathrm{mg}$; zinc, $50 \mathrm{mg}$; copper, $5 \mathrm{mg}$; and iodine, $0.2 \mathrm{mg}$.

mortality were recorded daily and feed intake was recorded weekly. Breakage was defined as the total number of broken, cracked, soft, and shell-less eggs. The individual body weight of the hens was measured every week from wk 0 to 4 , and every 2 wk from wk 6 to 12 of the experimental period; subsequently, body weight gain and loss were calculated. The number of hens that started molting was recorded during the molt-inducing period. Shell thickness of five eggs per replicate group was measured weekly during wk 0 to 2 , and then every 2 wk from wk 4 to 12 of the experimental period. The shell membrane was exfoliated, and the shell thickness was then measured at three places in the central part. On d 0,14, and 19 of the experimental period, five hens from each group were decapitated, and the ovary and oviduct weights of each hen were measured. On d 14, samples of the intestinal segment were taken from three hens of each group for scanning electron microscopy to assess the condition of the intestinal microvilli. On d 10 and 25, blood samples were taken from three hens of each group to 
determine the H:L ratios by using the methods described by McKee and Harrison (1995).

Data were analyzed by ANOVA using the JMP software (version 5.0.1), and the means were compared by Tukey's HSD test (SAS Institute Inc., 2002).

\section{Results}

\section{Feed Intake and Body Weight}

The feed intake on a weekly basis is stated in Table 2. For the control group, feed intake during the experimental period was $94.4 \sim 109.5 \mathrm{~g} / \mathrm{hen} / \mathrm{d}$. For the MS group, the feed intake at wk 3 was 61.8 $\mathrm{g} / \mathrm{hen} / \mathrm{d}$ due to skip feeding. For the MF group, the feed intake during the molt-inducing period was $53.9 \sim 69.4 \mathrm{~g} / \mathrm{hen} / \mathrm{d}$ due to feeding of the molt diet. During the molt-inducing period, the MF group had $(P<0.01)$ lower feed intake than did hens of the control group. At wk 0 and 12 of the experimental period, no significant differences $(P>0.05)$ were found among the treatments with regard to feed intake. Hens of the MS group lost $31.8 \%$ of their original body weight at wk 2, and those of the MF group lost $21.0 \%$ at wk 4 . No significant differences $(P>0.05)$ were found among the treatments with regard to body weight (Table 3 ) at wk 0,10 , and 12 .

Table 2. Effect of induced molting on feed intake of laying hens

\begin{tabular}{ccccc}
\hline \hline Periods & Control & MS $^{1)}$ & MF $^{2}$ & $P$ \\
$($ wk $)$ & & $(\mathrm{g} / \mathrm{hen} /$ day $)$ & \\
\cline { 2 - 4 } 0 & $108.8 \pm 2.7^{3)}$ & $110.6 \pm 2.6$ & $110.7 \pm 2.8$ & NS \\
1 & $103.4 \pm 1.8^{\mathrm{a}}$ & $0.0 \pm 0.0^{\mathrm{c}}$ & $53.9 \pm 2.9^{\mathrm{b}}$ & $* *$ \\
2 & $97.9 \pm 3.3^{\mathrm{a}}$ & $0.0 \pm 0.0^{\mathrm{c}}$ & $62.9 \pm 7.3^{\mathrm{b}}$ & $* *$ \\
3 & $99.1 \pm 9.0^{\mathrm{a}}$ & $61.8 \pm 0.8^{\mathrm{b}}$ & $69.4 \pm 11.6^{\mathrm{b}}$ & $* *$ \\
4 & $94.4 \pm 2.0^{\mathrm{a}}$ & $96.5 \pm 5.3^{\mathrm{a}}$ & $66.0 \pm 4.6^{\mathrm{b}}$ & $* *$ \\
5 & $100.2 \pm 1.6$ & $103.5 \pm 2.2$ & $103.9 \pm 3.0$ & $\mathrm{NS}$ \\
6 & $105.4 \pm 2.0^{\mathrm{b}}$ & $113.3 \pm 1.1^{\mathrm{a}}$ & $113.4 \pm 3.7^{\mathrm{a}}$ & $* *$ \\
7 & $105.0 \pm 3.4^{\mathrm{b}}$ & $114.3 \pm 0.9^{\mathrm{a}}$ & $116.3 \pm 3.1^{\mathrm{a}}$ & $* *$ \\
8 & $107.5 \pm 1.2^{\mathrm{b}}$ & $114.6 \pm 0.6^{\mathrm{a}}$ & $114.0 \pm 1.4^{\mathrm{a}}$ & $* *$ \\
9 & $109.5 \pm 2.9^{\mathrm{b}}$ & $114.7 \pm 0.3^{\mathrm{a}}$ & $114.4 \pm 0.9^{\mathrm{a}}$ & $* *$ \\
10 & $107.2 \pm 3.0^{\mathrm{b}}$ & $114.6 \pm 0.5^{\mathrm{a}}$ & $115.0 \pm 0.2^{\mathrm{a}}$ & $* *$ \\
11 & $102.1 \pm 6.5^{\mathrm{b}}$ & $114.1 \pm 1.0^{\mathrm{a}}$ & $114.5 \pm 0.6^{\mathrm{a}}$ & $* *$ \\
12 & $108.4 \pm 5.7$ & $113.8 \pm 1.8$ & $114.2 \pm 0.5$ & $\mathrm{NS}$ \\
\hline
\end{tabular}

${ }^{1)}$ MS: molting by starvation ( $\left.0-2 \mathrm{wk}\right)$.

${ }^{2)} \mathrm{MF}$ : molting with molt diet $(0-4 \mathrm{wk})$.

${ }^{3)}$ Data are presented as the mean \pm SD of 4 replicates per treatment.

$* * P<0.01$. NS: not significant.

${ }^{a b c}$ Means within a row followed by a common superscript are not significantly different.

Table 3. Effect of induced molting on body weight of laying hens

\begin{tabular}{ccccc}
\hline \hline Periods & Control & MS $^{1)}$ & MF $^{2)}$ & $P$ \\
\cline { 2 - 4 }$($ wk $)$ & & $(\mathrm{g})$ & \\
0 & $1666 \pm 21^{3)}$ & $1718 \pm 45$ & $1703 \pm 22$ & NS \\
1 & $1654 \pm 12^{\mathrm{a}}$ & $1302 \pm 34^{\mathrm{c}}$ & $1439 \pm 32^{\mathrm{b}}$ & $* *$ \\
2 & $1636 \pm 35^{\mathrm{a}}$ & $1171 \pm 33^{\mathrm{c}}$ & $1390 \pm 40^{\mathrm{b}}$ & $* *$ \\
3 & $1656 \pm 50^{\mathrm{a}}$ & $1386 \pm 34^{\mathrm{b}}$ & $1391 \pm 33^{\mathrm{b}}$ & $* *$ \\
4 & $1646 \pm 32^{\mathrm{a}}$ & $1520 \pm 56^{\mathrm{b}}$ & $1343 \pm 22^{\mathrm{c}}$ & $* *$ \\
6 & $1683 \pm 23^{\mathrm{a}}$ & $1620 \pm 32^{\mathrm{b}}$ & $1604 \pm 22^{\mathrm{b}}$ & $* *$ \\
8 & $1688 \pm 19^{\mathrm{a}}$ & $1628 \pm 13^{\mathrm{b}}$ & $1616 \pm 27^{\mathrm{b}}$ & $* *$ \\
10 & $1672 \pm 28$ & $1653 \pm 25$ & $1650 \pm 16$ & $\mathrm{NS}$ \\
12 & $1675 \pm 50$ & $1686 \pm 20$ & $1663 \pm 17$ & $\mathrm{NS}$ \\
\hline
\end{tabular}

${ }^{1)}$ MS: molting by starvation (0-2 wk).

${ }^{2)}$ MF: molting with molt diet (0-4 wk).

${ }^{3)}$ Data are presented as the mean \pm SD of 4 replicates per treatment.

$* * P<0.01$. NS: not significant.

${ }^{\text {abc }}$ Means within a row followed by a common superscript are not significantly different. 
Therefore, the hens of the molted groups had regained all their lost body weight. There were no differences $(P>0.05)$ in mortality among the treatments during the experimental period.

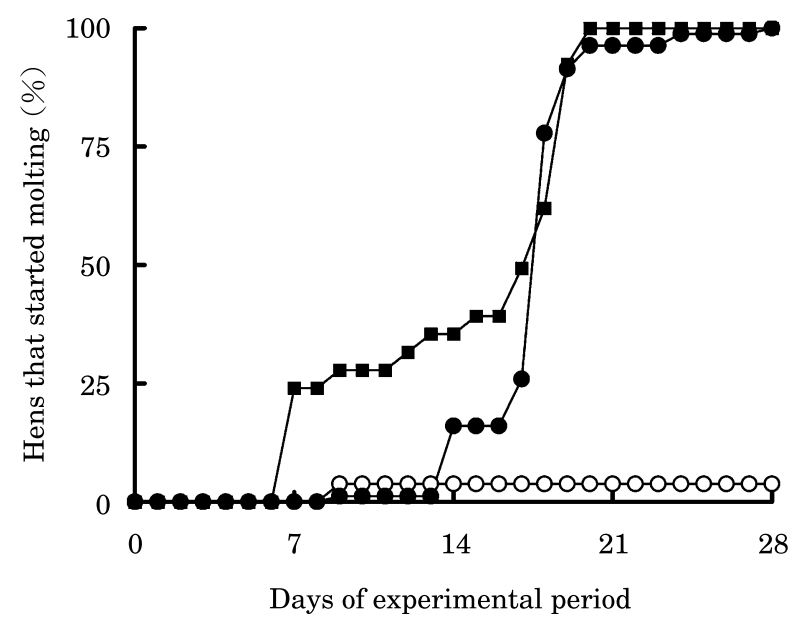

Fig. 1. The percentage of hens that started molting during the molt-inducing period of the control group (O), the hens of molting by starvation (MS: $\square$ ), and the hens of molting with molt diet (MF: $)$ ).

\section{Molting and Stress}

The percentage of hens that started molting during the molt-inducing period is presented in Fig. 1. The molting processes became evident from $\mathrm{d} 7$ and 9 of molt induction for the MS and MF groups, respectively. All hens of the MS and MF groups started molting on $\mathrm{d} 20$ and 28, respectively. At d 14 of the molt-inducing period, both the MS and MF groups had significantly lighter $(P<0.01)$ ovaries and oviducts than the control group; but no significant differences were found between the MS and MF groups (Table 4). At d 14 of the experiment, many intestinal microvilli were recognized in the control and MF groups; but these were not completely recognized in the MS group (Fig. 2). At d 10 of the experiment, the H:L ratios were significantly $(P<0.01)$ the highest for the MS group; but there were no significant differences $(P>0.05)$ among the treatments at $\mathrm{d} 25$ (Table 5).

\section{Post-molt Performance}

The rate of weekly egg production (excluding egg breakage) is shown in Table 6. Egg production in the MS group ceased by $\mathrm{d} 8$; and production was

Table 4. Effect of induced molting on ovary and oviduct weight of laying hens

\begin{tabular}{ccccc}
\hline \hline Periods & Control & $\mathrm{MS}^{1)}$ & $\mathrm{MF}^{2)}$ & $P$ \\
\cline { 2 - 2 }$($ day $)$ & $(\mathrm{g})$ & \\
0 & $112.0 \pm 10.0^{3)}$ & & & \\
14 & $120.2 \pm 19.6^{\mathrm{a}}$ & $18.9 \pm 4.1^{\mathrm{b}}$ & $21.7 \pm 1.4^{\mathrm{b}}$ & $* *$ \\
19 & & & $17.4 \pm 4.3$ & \\
\hline
\end{tabular}

${ }^{1)}$ MS: molting by starvation (0-2 wk).

${ }^{2)}$ MF: molting with molt diet $(0-4 \mathrm{wk})$.

${ }^{3)}$ Data are presented as the mean \pm SD of 5 hens per treatment.

** $P<0.01$.

${ }^{\text {abc }}$ Means within a row followed by a common superscript are not significantly different.

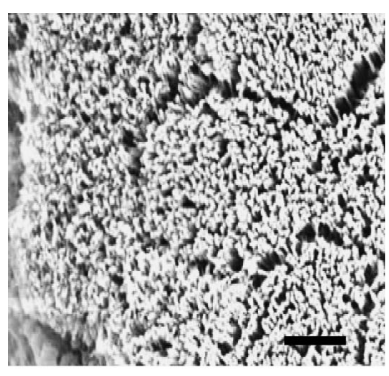

Control

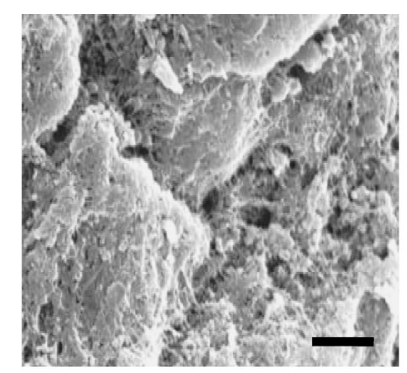

MS

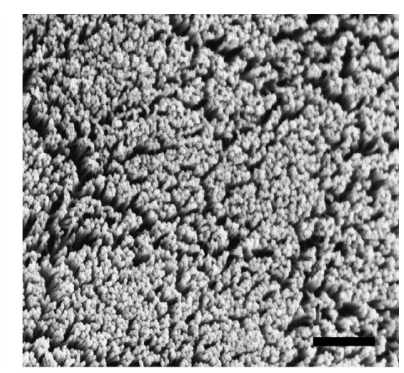

MF

Fig. 2. The condition of the intestinal microvilli in the control group, the hens of molting by starvation (MS), and the hens of molting with feed group (MF) at $\mathrm{d} 14$ of the experimental period. Scale bars represent $20 \mu \mathrm{m}$. 
Table 5. Effect of induced molting on heterophil: lymphocyte ratio (H:L ratio)

\begin{tabular}{|c|c|c|c|c|}
\hline Periods & Control & $\mathbf{M S}^{1)}$ & $\mathrm{MF}^{2)}$ & $P$ \\
\hline (day) & 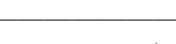 & - $(\mathrm{H}: \mathrm{L}$ ratio $)$ & 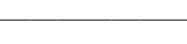 & \\
\hline 10 & $11.3 \pm 1.8^{\mathrm{b} 3)}$ & $36.7 \pm 5.9^{\mathrm{a}}$ & $24.5 \pm 12.1^{\mathrm{ab}}$ & $*$ \\
\hline 25 & $9.8 \pm 2.4$ & $10.4 \pm 4.5$ & $14.8 \pm 9.7$ & NS \\
\hline $\begin{array}{l}{ }^{1)} \text { MS: mo } \\
{ }^{2)} \text { MF: mo } \\
{ }^{3)} \text { Data ar } \\
{ }^{*} P<0.05\end{array}$ & $\begin{array}{l}\text { by starvation } \\
\text { with molt diet } \\
\text { sented as the } m \\
\text { not significan }\end{array}$ & k) 3 hens $p$ & tment. & \\
\hline
\end{tabular}

Table 6. Effect of induced molting on egg production ${ }^{1)}$ of laying hens

\begin{tabular}{ccccc}
\hline \hline Periods & Control & MS $^{2}$ & MF $^{3)}$ & $P$ \\
\cline { 2 - 4 }$($ wk $)$ & & & \\
\cline { 2 - 4 } & $87.5 \pm 3.2^{4)}$ & $89.5 \pm 0.7$ & $88.3 \pm 4.9$ & NS \\
1 & $87.3 \pm 3.2^{\mathrm{a}}$ & $42.0 \pm 2.9^{\mathrm{c}}$ & $67.6 \pm 3.2^{\mathrm{b}}$ & $* *$ \\
2 & $83.6 \pm 2.4^{\mathrm{a}}$ & $0.0 \pm 0.0^{\mathrm{c}}$ & $7.8 \pm 1.4^{\mathrm{b}}$ & $* *$ \\
3 & $78.1 \pm 8.3^{\mathrm{a}}$ & $0.0 \pm 0.0^{\mathrm{c}}$ & $5.0 \pm 2.3^{\mathrm{b}}$ & $* *$ \\
4 & $79.4 \pm 4.9^{\mathrm{a}}$ & $0.2 \pm 0.4^{\mathrm{c}}$ & $9.2 \pm 3.7^{\mathrm{b}}$ & $* *$ \\
5 & $79.4 \pm 1.9^{\mathrm{a}}$ & $32.0 \pm 10.0^{\mathrm{b}}$ & $6.3 \pm 3.2^{\mathrm{c}}$ & $* *$ \\
6 & $81.9 \pm 2.1^{\mathrm{a}}$ & $73.3 \pm 5.4^{\mathrm{b}}$ & $47.3 \pm 4.7^{\mathrm{c}}$ & $* *$ \\
7 & $84.5 \pm 5.7$ & $82.3 \pm 1.8$ & $83.5 \pm 1.9$ & $\mathrm{NS}$ \\
8 & $84.8 \pm 5.2$ & $88.4 \pm 4.2$ & $88.2 \pm 2.6$ & $\mathrm{NS}$ \\
9 & $80.1 \pm 4.6^{\mathrm{b}}$ & $92.4 \pm 3.7^{\mathrm{a}}$ & $88.8 \pm 3.8^{\mathrm{a}}$ & $* *$ \\
10 & $80.4 \pm 5.4^{\mathrm{b}}$ & $92.5 \pm 3.1^{\mathrm{a}}$ & $91.1 \pm 3.4^{\mathrm{a}}$ & $* *$ \\
11 & $80.7 \pm 5.6^{\mathrm{b}}$ & $94.3 \pm 1.4^{\mathrm{a}}$ & $93.3 \pm 2.6^{\mathrm{a}}$ & $* *$ \\
12 & $84.3 \pm 10.0$ & $93.9 \pm 2.6$ & $91.4 \pm 4.0$ & NS \\
\hline
\end{tabular}

${ }^{1)}$ Excluding egg breakage (broken, cracked, soft, and shell-less eggs).

${ }^{2)}$ MS: molting by starvation (0-2 wk).

${ }^{3)}$ MF: molting with molt diet (0-4 wk).

${ }^{4)}$ Data are presented as the mean \pm SD of 4 replicates per treatment.

$* * P<0.01$. NS: not significant.

${ }^{\text {abc }}$ Means within a row followed by a common superscript are not significantly different.

resumed $28 \mathrm{~d}$ after molt induction. The egg production of the MF group reached $3.8 \%$ on $\mathrm{d} 10$. At wk 7 , the egg production for all groups was over $80 \%$, and the post-molt egg production of the molted groups was significantly higher than that of the control group. No significant differences $(P>0.05)$ with regard to egg weight were found among the treatments at wk 0,5 , and 6 (Table 7). The eggs of the MF group were heavier than those of the MS and control groups (wk 7 to 12). No differences in the shell thickness of the eggs were observed among the treatments $(P>0.05)$ at wk 0, 6, and 8; but significant differences among the treatments $(P<$ 0.05 ) were observed from wk 10 to 12 (Table 8). The shell thickness of the eggs of the hens that had molted was also improved; but no significant differences were found between the MS and MF groups.

\section{Discussion}

In recent years, the induction of molting by temporary feed withdrawal has become the target of severe criticism from the viewpoint of both animal welfare and food safety concerns. The efforts of animal welfare activists to deny market access to eggs from molted flocks led to a policy decision by McDonald's Corporation (that buys more than 1 billion eggs each year) in 2000 to stop purchasing eggs from producers that use feed withdrawal in their molting programs (Gast and Ricke, 2003). Such policies have resulted in the need to evaluate alternative non-feed withdrawal methods for molting of laying hens (Biggs et al., 2003). Moreover, one of the guidelines of the United Egg Producers for inducing a molt is "Only non-feed withdrawal 
Table 7. Effect of induced molting on egg weight of laying hens

\begin{tabular}{ccccc}
\hline \hline Periods & Control & $\mathrm{MS}^{1)}$ & $\mathrm{MF}^{2)}$ & $P$ \\
\cline { 2 - 4 }$($ wk $)$ & & & \\
\cline { 2 - 4 } & $65.8 \pm 1.3^{3)}$ & $66.2 \pm 0.3$ & $66.4 \pm 0.9$ & NS \\
1 & $65.4 \pm 0.2^{\mathrm{a}}$ & $63.5 \pm 0.5^{\mathrm{b}}$ & $63.6 \pm 0.9^{\mathrm{b}}$ & $* *$ \\
2 & $65.8 \pm 0.1^{\mathrm{a}}$ & - & $62.2 \pm 2.5^{\mathrm{b}}$ & $*$ \\
3 & $66.2 \pm 0.3^{\mathrm{a}}$ & - & $60.3 \pm 1.5^{\mathrm{b}}$ & $* *$ \\
4 & $66.3 \pm 0.3^{\mathrm{a}}$ & - & $61.8 \pm 0.9^{\mathrm{b}}$ & $* *$ \\
5 & $66.7 \pm 0.4$ & $62.6 \pm 1.9$ & $66.1 \pm 5.3$ & $\mathrm{NS}$ \\
6 & $67.0 \pm 0.5$ & $67.5 \pm 0.9$ & $67.7 \pm 2.6$ & $\mathrm{NS}$ \\
7 & $67.4 \pm 0.4^{\mathrm{b}}$ & $68.0 \pm 0.3^{\mathrm{b}}$ & $70.3 \pm 1.1^{\mathrm{a}}$ & $* *$ \\
8 & $66.9 \pm 0.1^{\mathrm{c}}$ & $68.7 \pm 0.5^{\mathrm{b}}$ & $70.5 \pm 1.2^{\mathrm{a}}$ & $* *$ \\
9 & $66.9 \pm 0.2^{\mathrm{c}}$ & $68.7 \pm 0.8^{\mathrm{a}}$ & $69.7 \pm 0.9^{\mathrm{a}}$ & $* *$ \\
10 & $67.3 \pm 0.2^{\mathrm{b}}$ & $68.3 \pm 0.6^{\mathrm{ab}}$ & $69.4 \pm 0.7^{\mathrm{a}}$ & $* *$ \\
11 & $67.6 \pm 0.7^{\mathrm{b}}$ & $68.6 \pm 0.8^{\mathrm{ab}}$ & $69.6 \pm 1.1^{\mathrm{a}}$ & $*$ \\
12 & $67.6 \pm 0.7^{\mathrm{b}}$ & $68.6 \pm 0.6^{\mathrm{ab}}$ & $69.4 \pm 1.1^{\mathrm{a}}$ & $*$ \\
\hline
\end{tabular}

${ }^{1)}$ MS: molting by starvation (0-2 wk).

${ }^{2)}$ MF: molting with molt diet $(0-4 \mathrm{wk})$.

${ }^{3)}$ Data are presented as the mean \pm SD of 4 replicates per treatment.

$* * P<0.01 .{ }^{*} P<0.05$. NS: not significant.

${ }^{\text {abc }}$ Means within a row followed by a common superscript are not significantly different.

Table 8. Effect of induced molting on egg shell thickness ${ }^{1)}$ of laying hens

\begin{tabular}{ccccc}
\hline \hline Periods & Control & \multicolumn{1}{c}{$\mathrm{MS}^{2)}$} & $\mathrm{MF}^{3)}$ & $P$ \\
\cline { 2 - 4 }$(\mathrm{wk})$ & & $(\mathrm{mm})$ & \\
0 & $0.350 \pm 0.022^{4)}$ & $0.348 \pm 0.028$ & $0.357 \pm 0.022$ & $\mathrm{NS}$ \\
1 & $0.339 \pm 0.022^{\mathrm{a}}$ & - & $0.272 \pm 0.027^{\mathrm{b}}$ & $* *$ \\
2 & $0.345 \pm 0.020^{\mathrm{a}}$ & - & $0.310 \pm 0.019^{\mathrm{b}}$ & $* *$ \\
4 & $0.352 \pm 0.030^{\mathrm{a}}$ & $0.330 \pm 0.028^{\mathrm{ab}}$ & $0.311 \pm 0.030^{\mathrm{b}}$ & $* *$ \\
6 & $0.342 \pm 0.025$ & $0.358 \pm 0.029$ & $0.354 \pm 0.019$ & $\mathrm{NS}$ \\
8 & $0.350 \pm 0.021$ & $0.351 \pm 0.029$ & $0.343 \pm 0.030$ & $\mathrm{NS}$ \\
10 & $0.328 \pm 0.025^{\mathrm{b}}$ & $0.359 \pm 0.020^{\mathrm{a}}$ & $0.368 \pm 0.024^{\mathrm{a}}$ & $* *$ \\
12 & $0.334 \pm 0.021^{\mathrm{b}}$ & $0.362 \pm 0.026^{\mathrm{a}}$ & $0.359 \pm 0.026^{\mathrm{a}}$ & $* *$ \\
\hline
\end{tabular}

\footnotetext{
${ }^{1)}$ Average of egg shell thickness ( 3 places in the central part).

${ }^{2)}$ MS: molting by starvation ( $\left.0-2 \mathrm{wk}\right)$.

${ }^{3)} \mathrm{MF}$ : molting with molt diet (0-4 wk).

${ }^{4)}$ Data are presented as the mean \pm SD of 4 replicates per treatment.

$* * P<0.01$. NS: not significant.

${ }^{\mathrm{ab}}$ Means within a row followed by a common superscript are not significantly different.
}

molt methods will be permitted after January 1, 2006" (United Egg Producers, 2005).

In the present study, a molt diet resulted in decreased egg production and body weight during the molt period. Hens of the MF group lost more body mass than those of the control group due to decreased feed intake (approximately 40\%); this could be attributed to several factors including a higher percentage of wheat bran and corn gluten feed in the diet. Nevertheless, these results clearly confirmed that the molt diet was accepted by laying hens. The post-molt feed intake was higher than that of the unmolted birds. It may be due to the higher production rate and the rapid increase in body weight in the molted groups.

Regression of the ovary is the most important factor for molt induction because the loss of reproductive organ weight may be linked to the overall rejuvenation process (Brake and Thaxton, 1979; Brake, 1993). Therefore, in the present study, ovarian weight was measured as an indication of molting. Results of the present study show that the regression in the ovary weight of hens that were molted with the molt diet was equivalent to that of hens undergoing feed withdrawal; this indicated that the molt diet was effective in causing a sufficient 
regression of the reproductive organs that is essential for satisfactory post-molt performance. These findings are in agreement with those of Biggs et al. (2004) and Seo et al. (2001).

In the present study, the maximum body weight loss during molting for the MS and MF groups were $31.8 \%$ and $21.0 \%$, respectively, and significant differences were observed among the treatments $(P$ $<0.01)$ as stated in Table 3. However, there was no significant difference between the MS and MF groups with regard to ovarian regression (Table 4). These findings are in contrast with those of Baker et al. (1983) who reported that an approximately 30\% reduction in body weight is needed for successful ovary regression. Moreover, our findings are in contrast with those of Swanson and Bell (1974), Baker et al. (1981, 1983) and Zimmermann et al. (1987) who reported that in order to optimize post-molt performance, a body mass loss of $25 \%$ to $30 \%$ should be achieved. It was considered, for the optimum post-molt performance, that the maximum involution of the reproductive organs is more essential than 30\% body weight loss during the molting period.

The number of circulating leukocytes in chickens can be affected by various environmental and nutritional factors. Wolford and Ringer (1962) assessed the effects of various stressors on circulating leukocyte numbers in sexually mature Single Comb White Leghorn hens. In general, the percentage of lymphocytes decreased and the percentage of heterophils increased as a result of exposure to stressors. Gross and Siegel (1983) stated that H:L ratios are used for better measurement of the level of stressful conditions resulting from long-term changes in the environment. The H:L ratios of the molted groups were found to be higher than those of the control group. These results would indicate that molted birds were under more stress than control birds. However, the $\mathrm{H}: \mathrm{L}$ ratio of the MF group was lower than that of the MS group, suggesting that the molt treatment had very little effect on stress in the MF group. Similar results were reported by Wolford and Ringer (1962), Alodan and Mashaly (1999), Davis et al. (2000), and Webster (2003); in these studies, the H:L ratios were increased during induced molting by feed withdrawal. Fasting for 2 wk imposed severe physiological stress on the intestine because the intestinal microvilli were not com- pletely recognized in the MS group at $\mathrm{d} 14$. This finding was in agreement with the results reported by Yamauchi et al. (1996); in this study, the villus height of each intestinal segment gradually decreased with time after a 3-d fasting period. These results indicate that hens subjected to feed removal were under more stress than those not subjected to feed removal.

In the present experiment, the peak production of the hens in which molting was induced exceeded $90 \%$ at the post-molt period, and the rate of egg production was significantly improved by the molting treatments when compared with the control group. This result could be due to body weight loss as reported by Brake and Thaxton (1979), who indicated that higher is the body weight loss, higher is the post-molt production. These authors also reported that induced molting leads to the involution of the reproductive tract, which is proportional to the body weight loss, and that the rebuilding of the reproductive tract would lead to the removal of fat accumulation and therefore increased tissue efficiency. The results of the present study confirm earlier findings (Koelkebeck et al., 1993, 1999; Seo et al., 2001; Biggs et al., 2003, 2004) indicating that molting induced by non-feed removal results in increased egg production and improved shell quality that is the same as that obtained with molt procedures using limited feeding techniques.

In conclusion, the use of a nutrient-restricted molt diet effectively induced molting in hens, and the subsequent post-molt production was similar to that observed in hens subjected to long-term feed withdrawal. The hens of the MS group totally ceased egg production. Feeding the molt diet resulted in an almost complete cessation of egg production within $10 \mathrm{~d}$. In the present study, the metabolizable energy contents of the molt diet and layer ration were 2.27 and $2.85 \mathrm{Mcal} / \mathrm{kg}$, respectively. Therefore, the energy content of the molt diet is $79 \%$ that of the layer ration. The energy level of the diet appears to be an important factor in causing a rapid reduction in egg production (Biggs et al., 2004). Based on the results of this study, molts induced by the molt diet may not be sufficiently complete, and the heavier egg weights in the post-molt period may be due to the higher energy content of the molt diet. Further research will be conducted to determine the effects of the molt diet with other ingredients and to reduce the 
energy level of the molt diet for maximizing molt induction and post-molt egg quality.

\section{References}

Ahmad HA and Roland DA, Sr. Efficient feeding of molted hens with different feeding and formulation methods. International Journal of Poultry Science, 2: 383-388. 2003.

Alodan MA and Mashaly MM. Effect of induced molting in laying hens on production and immune parameters. Poultry Science, 78: 171-177. 1999.

Baker M, Brake $\mathbf{J}$ and McDaniel GR. The relationship between body weight loss during a forced molt and postmolt reproductive performance of caged layers. Poultry Science, 60: 1594. 1981.

Baker M, Brake J and McDaniel GR. The relationship between body weight loss during an induced molt and postmolt egg production, egg weight, and shell quality in caged layers. Poultry Science, 62: 409-413. 1983.

Biggs PE, Douglas MW, Koelkebeck KW and Parsons CM. Evaluation of nonfeed removal methods for molting programs. Poultry Science, 82: 749-753. 2003.

Biggs PE, Persia ME, Koelkebeck KW and Parsons CM. Further evaluation of nonfeed removal methods for molting programs. Poultry Science, 83: 745-752. 2004.

Brake $J$ and Thaxton P. Physiological changes in caged layers during a forced molt. 2. Gross changes in organs. Poultry Science, 58: 707-716. 1979.

Brake J. Recent advances in induced molting. Poultry Science, 72: 929-931. 1993.

Davis GS, Anderson KE and Carroll AS. The effects of long-term caging and molt of Single Comb White Leghorn hens on heterophil to lymphocyte ratios, corticosterone and thyroid hormones. Poultry Science, 79: 514-518. 2000.

Gast RK and Ricke SC. Symposium: Current and future prospects for induced molting in laying hens. Poultry Science, 82: 964. 2003.

Gross WB and Siegel HS. Evaluation of heterophil/lymphocyte ratio as a measure of stress in chickens. Avian Diseases, 27: 972-979. 1983.

Holt PS. Effects of induced moulting on immune responses of hens. British Poultry Science, 33: 165-175. 1992.

Holt PS. Molting and Salmonella Enterica Serovar Enteritidis infection: The problem and some solutions. Poultry Science, 82: 1008-1010. 2003.

Keshavarz K and Quimby FW. An investigation of different molting techniques with an emphasis on animal welfare. Journal of Applied Poultry Research, 11: 54-67. 2002.

Koelkebeck KW, Parsons CM, Leeper RW and Wang X.
Effect of supplementation of a low-protein corn molt diet with amino acids on early postmolt laying hen performance. Poultry Science, 72: 1528-1536. 1993.

Koelkebeck KW, Parsons CM, Leeper RW, Jin S and Douglas MW. Early post-molt performance of laying hens fed a low-protein corn molt diet supplemented with corn gluten meal, feather meal, methionine, and lysine. Poultry Science, 78: 1132-1137. 1999.

McKee JS and Harrison PC. Effects of supplemental ascorbic acid on the performance of broiler chickens exposed to multiple concurrent stressors. Poultry Science, 74: 17721785. 1995.

North MO and Bell DD. Commercial Chicken Production Manual. 4th ed. Chapman and Hall, New York. 1990.

Park SY, Kim WK, Birkhold SG, Kubena LF, Nisbet DJ and Ricke SC. Induced moulting issues and alternative dietary strategies for the egg industry in the United States. World's Poultry Science Journal, 60: 196-209. 2004.

Ricke SC. The gastrointestinal tract ecology of Salmonella Enteritidis colonization in molting hens. Poultry Science, 82: 1003-1007. 2003.

Ruszler PL. Health and husbandry considerations of induced molting. Poultry Science, 77: 1789-1793. 1998.

SAS Institute Inc., One-Way ANOVA. In: JMP Statistics and Graphic Guide, version 5. pp. 89-126. SAS Institute Inc., Cary, NC, USA. 2002.

Seo K-H, Holt PS and Gast RK. Comparison of Salmonella Enteritidis infection in hens molted via long-term feed withdrawal versus full-fed wheat middling. Journal of Food Protection, 64: 1917-1921. 2001.

Swanson MH and Bell DD. Force Molting of Chickens. II. Methods. University of California Leaflet 2650, University of California, Davis, California. 1974.

United Egg Producers. Animal Husbandry Guidelines for U. S Egg Laying Flocks. 2nd ed. 2005.

Webster AB. Physiology and behavior of the hen during induced molt. Poultry Science, 82: 992-1002. 2003.

Wolford JH and Ringer RK. Adrenal weight, adrenal ascorbic acid, adrenal cholesterol and differential leukocyte counts as physiological indicators of "stressor" agents in laying hens. Poultry Science, 41: 1521-1529. 1962.

Yamauchi K, Kamisoyama $\mathrm{H}$ and Isshiki $\mathrm{Y}$. Effects of fasting and refeeding on structures of the intestinal villi and epithelial cells in White Leghorn hens. British Poultry Science, 37: 909-921. 1996.

Zimmermann NG, Andrews DK and McGinnis J. Comparison of several induced molting methods on subsequent performance of Single Comb White Leghorn hens. Poultry Science, 66: 408-417. 1987. 